\title{
Topoisomerase II Is Required for Mitoxantrone to Signal Nuclear Factor $\kappa$ B Activation in HL60 Cells*
}

Received for publication, May 4, 2000, and in revised form, May 31, 2000 Published, JBC Papers in Press, June 5, 2000, DOI 10.1074/jbc.M003794200

\author{
Marion P. Boland‡, Katherine A. Fitzgerald, and Luke A. J. O’Neill§ \\ From the Department of Biochemistry and Biotechnology Institute, Trinity College, Dublin 2, Ireland
}

\begin{abstract}
Topoisomerase II is a target for a number of chemotherapeutic agents used in the treatment of cancer. Its essential physiological role in modifying the topology of DNA involves the generation of transient double-strand breaks. Anti-cancer drugs, such as mitoxantrone, that target this enzyme interrupt its catalytic cycle and give rise to persistent double strand breaks, which may be lethal to a cell. We investigated the role of such lesions in signaling the activation of the transcription factor nuclear factor $\kappa \mathrm{B}(\mathrm{NF} \kappa \mathrm{B})$ by this drug. Mitoxantrone activated NF $\kappa \mathrm{B}$ and stimulated $\mathrm{I} \kappa \mathrm{B} \alpha$ degradation in the promyelocytic leukemia cell line HL60 but not in the variant cells, HL60/MX2 cells, which lack the $\beta$ isoform of topoisomerase II and express a truncated $\alpha$ isoform that results in an altered subcellular distribution. Treatment of sensitive HL60 cells with mitoxantrone led to a depletion of both isoforms, suggesting the stabilization of transient DNA-topoisomerase II complexes. This depletion was absent in the variant cells, HL60/MX2. Activation of caspase 3 by mitoxantrone was also impaired in the HL60/MX2 cells. NF $\kappa B$ activation in response to tumor necrosis factor and bleomycin, the latter causing topoisomerase II-independent DNA damage, was intact in both cell lines. An inhibitor rather than a poison of topoisomerase II, Imperial Cancer Research Fund 187 (ICRF 187) the mechanism of which does not involve the generation of double strand breaks, did not activate NF $\kappa B$, nor did it induce apoptosis in parental HL60 cells. However, ICRF 187 protected against I $\mathrm{K}$ degradation in parental HL60 cells in response to mitoxantrone. This protection was also shown with another topoisomerase II inhibitor, merbarone, which is structurally and functionally distinct from ICRF 187. Their effects were specific, as neither protected against tumor necrosis factorstimulated I $\mathrm{K}$ degradation. The poisoning of topoisomerase II with resultant DNA damage is therefore a critical signal for NF $\kappa$ B activation.
\end{abstract}

Agents that induce stress in cells, such as ionizing radiation, reactive oxygen species, and anti-neoplastic drugs, change the expression of many genes by affecting transcription factors, including $\mathrm{AP} 1, \mathrm{NF}-\mathrm{AT}, \mathrm{NF}_{\kappa} \mathrm{B},{ }^{1}$ and Egr-1 (1-7). Such genes may encode proteins that determine the commitment of a cell to

* This work was supported by funding from a grant from the Cancer Research Advancement Board, Ireland (to M. P. B. and L. A. J. O.). The costs of publication of this article were defrayed in part by the payment of page charges. This article must therefore be hereby marked "advertisement" in accordance with 18 U.S.C. Section 1734 solely to indicate this fact.

\$ Present address: Dept. of Pathology, University of Cambridge, Tennis Court Rd., Cambridge, CB2 1QP, United Kingdom.

$\S$ To whom correspondence should be addressed. Tel.: 353-1-6082439; Fax: 353-1-677-2400; E-mail: laoneill@tcd.ie.

${ }^{1}$ The abbreviations used are: $\mathrm{NF}_{\kappa} \mathrm{B}$, nuclear factor $\kappa \mathrm{B}$; TNF, tumor mitotic arrest, damage repair, proliferation, or even apoptosis. The regulation and role of the inducible transcription factor $\mathrm{NF} \kappa \mathrm{B}$ has been studied intensely during recent years. $\mathrm{NF} \kappa \mathrm{B}$ is present in diverse cell types, activated in response to diverse stimuli by complex signaling pathways involving several protein-protein interactions and phosphorylations (8-10). Typically, $\mathrm{NF} \kappa \mathrm{B}$ resides in the cytosol as a dimer composed of subunits belonging to the Rel family of proteins, the prototype comprising a p50 and p65/RelA subunit. p50/p65(RelA) heterodimers have a potent transcriptional activating potential, whereas p50 homodimers lack transactivation activity due to the absence of a transcriptional activation domain $(9,11,12)$.

$\mathrm{NF} \kappa \mathrm{B}$ heterodimers are sequestered in the cytosol through interactions with an inhibitor protein termed $\mathrm{I} \kappa \mathrm{B}$, of which there are a number of isoforms (13). The classical pathway to $\mathrm{NF} \kappa \mathrm{B}$ activation involves the phosphorylation of $\mathrm{I} \kappa \mathrm{B} \alpha$ on two critical serine residues at positions 32 and 36, within its aminoterminal regulatory domain (14). Once phosphorylated, $\mathrm{I} \kappa \mathrm{B} \alpha$ is subjected to polyubiquitination at two lysine residues, which also reside within this domain (15) and which target the protein for subsequent degradation by the $26 \mathrm{~S}$ proteasome (16), unmasking the nuclear localization signal of the heterodimer and allowing it to translocate into the nucleus, where it binds to the promoter regions of genes and stimulates transcription. Two I $\kappa$ B kinases, $\alpha$ and $\beta$ (reviewed in Ref. 17), in a complex with an accessory protein, $\mathrm{NF}_{\kappa} \mathrm{B}$ essential modulator, have been shown to be responsible for the phosphorylation of $\mathrm{I} \kappa \mathrm{B}$ (18-20).

Cytokines, such as interleukin 1 and $\mathrm{TNF}$, activate $\mathrm{NF} \kappa \mathrm{B}$ by recruiting a number of receptor-interacting proteins (reviewed in Refs. 21 and 22), which lead to the activation of $\mathrm{NF}_{\kappa} \mathrm{B}$ inducing kinase, which then activates the inhibitor of $\kappa \mathrm{B}$ kinase complex $(17,23)$, although a role for $\mathrm{NF} \kappa \mathrm{B}$-inducing kinase has recently been questioned (24). Other potent activators of $\mathrm{NF}_{\kappa} \mathrm{B}$ are anthracycline anti-cancer drugs, such as daunorubicin, and the related anthracenedione, mitoxantrone (2). Similar to other $\mathrm{NF}_{\kappa} \mathrm{B}$ activators, their effects appear to involve reactive oxygen species $(2,3,25)$. The primary target for these drugs and/or the nature of the lesion induced that mediates the signal leading to $\mathrm{NF}_{\kappa} \mathrm{B}$ activation is unknown, however. Like many chemotherapeutic agents, these drugs exert their anti-neoplastic effects in susceptible cells by inducing apoptosis (26). The mechanism by which anthracycline-type drugs kill cells has been proposed to involve intercalation of the planar aglycone moiety into the DNA (affecting DNA replication and transcription) and redox cycling resulting in the oxidative damage of cellular macromolecules and lipid membranes (reviewed in Ref. 27). However, given that mitoxantrone causes minimal oxidative stress in target cells $(28,29)$, its

necrosis factor; FBS, fetal bovine serum; ICRF187, Imperial Cancer Research Fund 187. 
apoptotic effects can be exclusively correlated with its ability to induce DNA damage, specifically DNA double strand breaks, by direct interaction with a family of enzymes known as type II topoisomerases (30).

Collectively, these enzymes affect the topology of DNA, and their importance is underscored by their involvement in virtually every aspect of DNA metabolism, chromosomal organization, and segregation $(31,32)$. There are two isoforms of topoisomerase II enzymes in mammalian cells, an $\alpha$ and a $\beta$ form, which differ in their molecular weight and are the products of two separate genes. Their amino-terminal sequence is highly conserved, but they only maintain $35 \%$ homology in their carboxyl termini, which has been proposed to account for differences in their cellular distribution $(31,33)$. The $\alpha$ form is localized to the nuclear matrix, whereas the $\beta$ form is nonmatrix-associated and localizes preferentially in the nucleoli. A nucleolar localization has, however, been disputed recently, with evidence being presented for the $\beta$ form being nuclear but not nucleolar (34). These enzymes may have distinct and overlapping physiological roles, suggested by their differential expression and phosphorylation during mitosis and transformation $(31,32)$. The $\alpha$ form, a substrate for casein kinase II (35), may be preferentially involved in DNA transcription accounting for its enhanced expression during mitosis (36). In this regard, it has been termed a proliferative marker. The $\beta$ form has been proposed to have a preferential role in ribosomal RNA transcription and is excluded from the nuclear scaffold during mitosis, diffusing into the cytosol $(32,33)$. The expression of this isoform generally increases during transformation, in contrast with its more constitutive expression in normal cells, suggesting a role for it in transformation.

Topoisomerase II enzyme action involves sequential DNA binding, cleavage of the DNA phosphodiester backbone, intact second strand passage, religation of the cleaved DNA strand, and enzyme turnover, which is an energy-dependent process involving the hydrolysis of ATP (30). Anthracycline and related anthracenedione drugs stabilize or "trap" the intermediate in this reaction, giving rise to a "cleavable complex" and are therefore termed "poisons." This trapping is thought to block or prevent the religation step and gives rise to the presence of protein-associated double strand breaks. In effect, anthracyclines and anthracenediones form ternary complexes with DNA and the enzyme and stimulate DNA cleavage in a sequencespecific manner (37). Correlations between the level of target enzyme, drug induced strand breaks, and sensitivity toward drug-induced cell killing have been shown (38), although there remains some controversy regarding the preferential targeting of different isoforms by different categories of topoisomerase II-targeted drugs (39-43). A recent study has shown that drugs such as mitoxantrone can target both topoisomerase II $\alpha$ and $\beta$ (44). Topoisomerase II $\beta$ may be the more important target, however, as cells deficient in this form are less sensitive to killing by mitoxantrone (44).

In this study, we have investigated the role of topoisomerase II in $\mathrm{NF}_{\kappa} \mathrm{B}$ activation by mitoxantrone. We have utilized a resistant variant of the promyelocytic cell line HL60, termed HL60/MX2, which, compared with the parental line, is 34-fold more resistant to cell killing by mitoxantrone $(45,46)$. This resistance has been correlated with a complete absence of the expression of the topoisomerase II $\beta$ isoform. Furthermore, the topoisomerase II $\alpha$ transcript has a deletion in its $3^{\prime}$ end, resulting in a truncated protein with altered subcellular distribution and possibly altered drug sensitivity (47). Our data support a direct relationship between cell killing, $\mathrm{NF}_{\kappa} \mathrm{B}$ activation, and the targeting of topoisomerase II enzymes by this drug, indicating a novel pathway to $\mathrm{NF}_{\kappa} \mathrm{B}$ activation involving
DNA double strand breaks generated by the poisoning of topoisomerase II.

\section{EXPERIMENTAL PROCEDURES}

Materials--HL60 parental and resistant (HL60/MX2) cells were kindly supplied by Dr. Ian Hickson (ICRF, University of Oxford, Oxford, United Kingdom) (43) and were grown in suspension culture in RPMI 1640 medium supplemented with $20 \%$ fetal calf serum, penicillin/streptomycin (100 units $/ \mathrm{ml}$ and $100 \mu \mathrm{g} / \mathrm{ml}$, respectively) and L-glutamine (final concentration, $2 \mathrm{~mm}$ ), all obtained from Life Technologies, Inc. Mitoxantrone and recombinant human $\mathrm{TNF} \alpha$ were generous gifts from Wyeth-Ayerst Research (Berks, United Kingdom) and Zeneca Pharmaceuticals Ltd. (Macclesfield, United Kingdom), respectively. ICRF 187 was kindly supplied by Dr. Maxwell Sehested (Department of Pathology, Laboratory Center Rigshospitalet, Copenhagen, Denmark) and Dr. A. M. Creighton (Medicinal Chemistry Laboratory, St. Bartholomew's Hospital Medical College, London, United Kingdom). Merbarone was a gift from Professor William T. Beck (Division of Therapeutics, Cancer Center, College of Medicine, University of Illinois at Chicago, Chicago, IL). Poly(dI-dC) was purchased from Amersham Pharmacia Biotech. T4 polynucleotide kinase and oligonucleotide containing the consensus sequence 5'-GG GAC TTT CC-3', corresponding to the $\kappa$ light chain enhancer motif, were purchased from Promega (Southampton, United Kingdom). $\left[\gamma^{32} \mathrm{P}\right]$ ATP $(3000 \mathrm{Ci} / \mathrm{mmol})$, was from Amersham Pharmacia Biotech. Phototope ${ }^{\mathrm{TM}}$ horseradish peroxidase Western blot detection kit was from New England Biolabs Ltd. Monoclonal antibodies to the inhibitor protein, $\mathrm{I}_{\kappa} \mathrm{B} \alpha$, were a generous gift from Dr. Ron Hay (St. Andrews, United Kingdom). Monoclonal antibodies to human DNA topoisomerase II ( $\alpha$ and $\beta$ ) and CPP32 enzymes were purchased from Genosys Biotechnologies Inc. (Cambridge, United Kingdom) and Transduction Laboratories (Lexington, KY), respectively. Rabbit polyclonal antibodies to topoisomerase II $\alpha$ and $\beta$ were generously provided by $\mathrm{Dr}$. Ian Hickson (ICRF, University of Oxford). All other reagents were purchased from Sigma.

Cell Culture-For treatments, cells in late log phase of growth were resuspended in complete medium supplemented with 0.5\% FBS at a concentration of $1 \times 10^{6} \mathrm{cells} / \mathrm{ml}$ and incubated at $37^{\circ} \mathrm{C}$ in a humidified atmosphere of $5 \% \mathrm{CO}^{2} / 95 \%$ air (for $16 \mathrm{~h}$ prior to stimulation). Following stimulation ( $4 \mathrm{~h}$ unless otherwise stated), incubations were discontinued by the addition of ice-cold phosphate-buffered saline, and either nuclear or whole cell extracts (for $\mathrm{I} \kappa \mathrm{B}$ and CPP32 determinations) were prepared as described previously (2). Treatments using the radiomimetic drug bleomycin were carried out for $2 \mathrm{~h}$ only. Where required, cells were preincubated with the topoisomerase II inhibitors ICRF 187 or merbarone for $1 \mathrm{~h}$, prior to the addition of either drug $(4 \mathrm{~h})$ or cytokine $(1 \mathrm{~h})$. Cell extracts for the analysis of topoisomerase II isoform content were prepared according to the method described by Drake et al. (48). Protein concentration determinations were made using the Bradford assay with bovine albumin as standard.

Electrophoretic Mobility Shift Assays-Nuclear NF $\kappa \mathrm{B}$ was assessed by the electrophoretic mobility shift assay using a 22-base pair oligonucleotide containing the human $\kappa$ light chain enhancer motif, which had previously been end-labeled with $\left[\gamma^{32} \mathrm{P}\right]$ ATP as described (2). Typically, 2-4 $\mathrm{mg}$ of nuclear extract protein was incubated with radiolabeled oligonucleotide $(10,000 \mathrm{cpm})$ at room temperature for 30 min using the conditions described previously $(2,11)$. NF $\kappa \mathrm{B}$ complexes were resolved on 5\% acrylamide gels and identified following autoradiography.

Western Blot Analysis-Equal amounts of whole cell lysate protein (as indicated) were resolved by SDS-polyacrylamide gel electrophoresis (10\% running gel) and transferred onto nitrocellulose, and $\mathrm{I}_{\kappa} \mathrm{B} \alpha$ or CPP32 immunoblot analysis was performed as described previously (2, 11). Samples for topoisomerase II protein detection were resolved on $7 \%$ gels and, following transfer, incubated with primary antibody at a dilution of $1: 250(0.4 \mu \mathrm{g} / \mathrm{ml})$ in $1 \%$ dry milk in $1 \times$ phosphate buffered saline and $0.5 \%$ Tween 20 . Secondary antibody was used at a dilution of 1:1000. The blots were developed by chemiluminescent detection (ECL) according to the manufacturer's recommendation.

Band Depletion Assay for Topoisomerase II-Following treatment, cells were harvested by centrifugation, and nuclear extracts were prepared as described previously (48). Samples were resolved on $7 \%$ gels and, following transfer, incubated with primary antibody to both topoisomerase II isoforms (as described above) or with isoform-specific antibodies (polyclonal) at a dilution of 1:500; samples were resolved in 1\% dry milk in $1 \times$ phosphate buffered saline and $0.5 \%$ Tween 20 . Secondary antibody concentrations and detection were also as described above. 
RESULTS

Mitoxantrone Activates $N F \kappa B$ and Stimulates $I_{\kappa} B$ Degradation in Parental HL60 Promyelocytic Cells but not in the Variant Cells, HL60/MX2-Previously we have shown that mitoxantrone could activate $\mathrm{NF}_{\kappa} \mathrm{B}$ in a dose-dependent manner in HL60 promyelocytic leukemia cells (2). In this report, we have compared this activation with that in a derived variant of this cell line, HL60/MX2 (42-44), which has reduced levels of both topoisomerase II $\alpha$ and $\beta$ and is resistant to cell kill by mitoxantrone. $\mathrm{NF}_{\kappa} \mathrm{B}$ activation was not observed in the HL60/MX2 cell line, compared with a dose-responsive activation in the parental cell line, demonstrated by the detection of proteinDNA complexes in nuclear extracts from drug-treated cells (Fig. 1A). Concentrations of 50-1000 nM mitoxantrone activated $\mathrm{NF}_{\kappa} \mathrm{B}$ (lanes 2-6) in the parental line, whereas these concentrations were ineffective in the HL60/MX2 cell line (lanes 8-12). However, both cell lines showed comparable $\mathrm{NF}_{\kappa} \mathrm{B}$ activation following stimulation with the cytokine, TNF (2 ng/ml) (lanes 13 and 14, respectively). A dose-dependent degradation of the inhibitor protein, $\mathrm{I} \kappa \mathrm{B} \alpha$, a key signal for $\mathrm{NF} \kappa \mathrm{B}$ activation (9), was also observed in the parental but not the HL60/MX2 cell line in response to mitoxantrone (Fig. 1B). Concentrations from $500 \mathrm{~nm}$ clearly induced I $\kappa \mathrm{B}$ degradation in the parental line (lanes $3-5$ ) but not in the HL60/MX2 cell line (Fig. 1B, lanes 9-11), which supported the $\mathrm{NF} \kappa \mathrm{B}$ activation data. This degradation was comparable in both cell lines in response to TNF (2 ng/ml) (Fig. 1B, compare lanes 6 and 12). We also tested another DNA damaging agent in both cell lines, bleomycin, the effects of which are not topoisomerase II-dependent (49). This agent induced $\mathrm{I} \kappa \mathrm{B} \alpha$ degradation in both HL60 and HL60/MX2 cells (Fig. 1C, compare lanes 1 and 2 with lanes 3 and 4), although its effect was less pronounced than mitoxantrone in parental HL60 cells or TNF in both cell lines (Fig. 1B). Although bleomycin was a weaker activator of $\mathrm{NF} \kappa \mathrm{B}$, this may be explained by its ability to cause DNA strand scission resulting in both single and double strand breaks, the former perhaps being a less potent signal for this effect. Densitometric scanning performed on the immunoblot data (Fig. $1 C$ ) showed similar levels of $\mathrm{I} \kappa \mathrm{B} \alpha$ degradation (47 and $45 \%$ ) when compared with control values for both parental and variant HL60/MX2 cells in response to bleomycin. Non-topoisomerase II-targeted drugs that damage DNA can therefore activate $\mathrm{NF} \kappa \mathrm{B}$ and are independent of the topoisomerase II levels in target cells.

Both Topoisomerase II Isoforms Are Present in Parental HL60 Cells and Are Targeted by Mitoxantrone-To confirm the phenotype of both cell lines, Western blot analysis of whole cell extracts was performed with an antibody that recognized both the $\alpha$ and $\beta$ isoforms of the topoisomerase II enzyme (Fig. 2A). Both isoforms were detected in the parental cell line (Fig. $2 A$, lane 1-3), whereas expression of the $\beta$ isoform was negligible in extracts from the HL60/MX2 cells (lane 4-6). The expression of both isoforms was unaffected by treatment of cells with mitoxantrone (250 and $500 \mathrm{~nm}$, Fig. 2A, lanes 2-3 and 5-6). Formation of transient DNA-topoisomerase II complexes is stabilized by some topoisomerase II poisons, such as mitoxantrone. Employing a band depletion assay on nuclear extracts from treated cells, the functionality of either the drug or the topoisomerase II target can be determined (50). Following treatment of parental HL60 cells with mitoxantrone (Fig. $2 B$ ), the intensity of a band representing both isoforms decreased as drug concentration increased (Fig. 2B, lanes 1-4). The extraction protocol used in the band depletion assay prevented the resolution of both topoisomerase II isoforms, which migrated as a single band. Importantly, no band depletion was seen following treatment of the resistant variant cells, HL60/MX2 (lanes 5-7). Further- more, employing an antibody that recognizes the $\alpha$ isoform of topoisomerase II (Fig. 2C), its specific depletion was shown in parental HL60 cells (lanes 1-4) but not in the variant cells, HL60/MX2 (lanes 5-8), confirming the resistance of the $\alpha$ isoform to mitoxantrone in the HL60/MX2 line. In addition, when an antibody that specifically recognizes the $\beta$ isoform of topoisomerase II was used, mitoxantrone treatment caused a depletion of the $\beta$ isoform in parental HL60 cells, (Fig. 2D, lanes 1-4). Again, no $\beta$ isoform expression could be detected in the variant cell line (Fig. $2 D$, lanes $5-8$ ).

These data clearly show that mitoxantrone dose-dependently stabilizes topoisomerase II in parental HL60 cells, but this effect is absent in variant HL60/MX2 cells, which are deficient in the $\beta$ isoform and have a mutated $\alpha$ isoform. $\mathrm{NF}_{\kappa} \mathrm{B}$ activation in response to this drug is therefore dependent on the presence of functional topoisomerase II, although components necessary to give rise to this activation are normally present in both cells, as $\mathrm{NF}_{\kappa} \mathrm{B}$ was activated equally by $\mathrm{TNF}$ and bleomycin.

Mitoxantrone Activates Caspase 3 Degradation in Parental HL60 Cells but not in the Variant HL60/MX2 Cell Line-In order to confirm the reported phenotype of these cells and correlate $\mathrm{NF} \kappa \mathrm{B}$ activation with either sensitivity or resistance to drug-induced cell kill, we measured the apoptotic response of parental and variant HL60/MX2 cells (Fig. 3). We utilized degradation of the pro-form of caspase 3 as a marker for apoptosis (51), because this could be detected in the same extracts used to study $\mathrm{I} \kappa \mathrm{B}$ degradation (as shown in Fig. $1 B$ ). Caspase 3 degradation was induced by mitoxantrone in the parental (lanes 2-4) but not the variant HL60/MX2 cells (lanes 7-9). This suggested induction of an apoptotic program of cell death in the parental HL60 but not the variant HL60/MX2 cells. However, both cell lines were equally sensitive to apoptotic induction by other stimuli, as measured by caspase 3 degradation. TNF/cycloheximide (10 ng/ml and $100 \mu \mathrm{M}$; lanes 6 and 10) induced pro-caspase 3 degradation in both HL60 parental and HL60/MX2 cells. Morphological analysis of cells showed a similar result, with mitoxantrone inducing changes indicative of apoptosis in the parental but not in the HL60/MX2 cell line (data not shown). Our data therefore support the reported phenotype of these cells $(45,46,52)$ and show that sensitivity to apoptotic induction correlates with the ability of the same doses of mitoxantrone to activate $\mathrm{NF}_{\kappa} \mathrm{B}$, the effect being dependent on the presence of functional topoisomerase II isoforms.

ICRF 187, an Inhibitor of Topoisomerase II Enzymes, Does Not Activate $N F_{\kappa} B$, Nor Does It Induce Apoptosis in Parental HL60 Promyelocytic Cells-We attempted to complement the HL60/MX2 variant cells with both topoisomerase II isoforms but had difficulty expressing the enzymes in these cells. We therefore adopted a second strategy to provide further evidence to support a role for topoisomerase II. This involved the use of an inhibitor, ICRF 187, which blocks topoisomerase II activity but does not generate protein-associated DNA double-strand breaks like mitoxantrone (reviewed in Ref. 53). It can be used to protect against the induction of DNA double strand breaks and subsequent toxicity induced by such poisons by blocking their ability to interact with their topoisomerase II targets (54, $55)$. First, we tested whether ICRF 187 could activate $\mathrm{NF} \kappa \mathrm{B}$ on its own. Treatment of parental HL60 cells with ICRF 187 resulted in a much weaker activation of $\mathrm{NF} \kappa \mathrm{B}$, as demonstrated by the detection of DNA-protein complexes in nuclear extracts from control and treated cells (Fig. 4A, lanes 3-8). However, $\mathrm{NF} \kappa \mathrm{B}$ activation comparable to treatment with $1 \mu \mathrm{M}$ mitoxantrone (lane 9) was seen at a dose of $500 \mu \mathrm{M}$ ICRF 187 (lane 8), indicating that topoisomerase II poisoning, rather 
A HL60

HL60/MX2

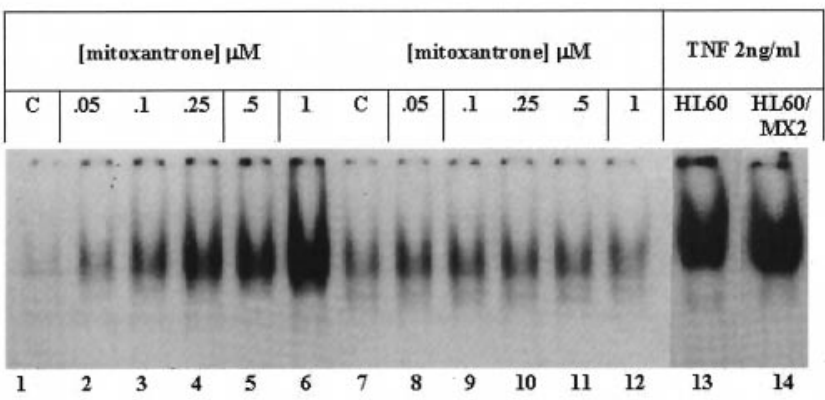

B

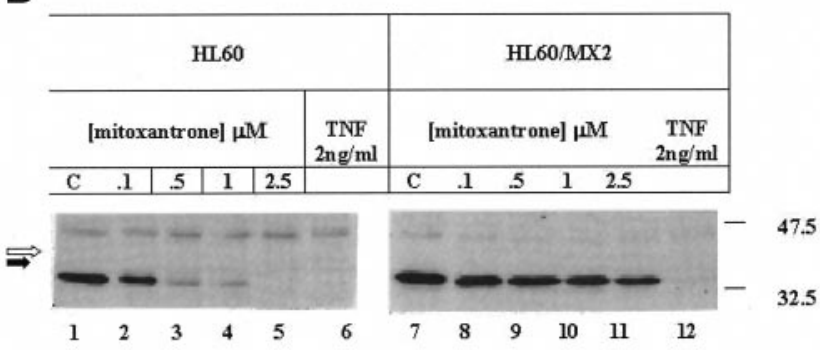

C

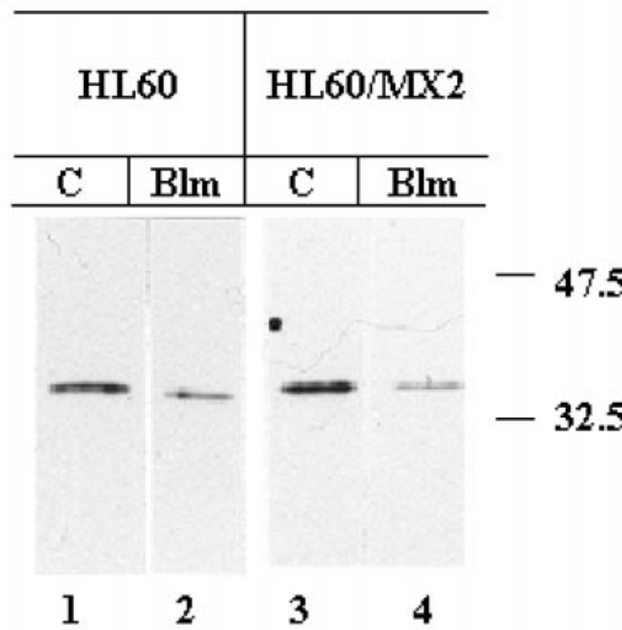

FIg. 1. Mitoxantrone activates NF $\boldsymbol{B}$ and stimulates $I_{\kappa} \mathrm{B}$ degradation in parental HL60 promyelocytic leukemia cells but not in the variant MX2 cell line, which lacks topoisomerase II $\beta . A$, HL60 cells (either parental or MX2), seeded overnight $\left(1 \times 10^{6} / \mathrm{ml}\right)$ in media supplemented with $0.5 \% \mathrm{FBS}$, were treated with either mitoxantrone (concentrations indicated) (lanes 2-6 and 8-12) or an equivalent volume of vehicle control $(C)$ (media) (lanes 1 and 7) for $4 \mathrm{~h}$. Alternatively, cells were treated with TNF $(2 \mathrm{ng} / \mathrm{ml}$ ) (lanes 13 and 14) for $1 \mathrm{~h}$. Nuclear extracts were prepared following stimulation and analyzed for $\mathrm{NF}_{\kappa} \mathrm{B}$ binding activity as described under "Experimental Procedures." NF $\kappa$ B-DNA complexes are shown. Results are representative of three separate experiments. B, HL60 cells (either parental or MX2), seeded overnight $\left(1 \times 10^{6} / \mathrm{ml}\right)$ in media supplemented with $0.5 \%$ FBS ( $3 \mathrm{ml}$ total), were treated with either mitoxantrone (concentrations indicated) (lanes 2-5 and 8-11) or an equivalent volume of vehicle control (media) (lanes 1 and 7 ) for $4 \mathrm{~h}$. Alternatively, cells were treated with TNF ( $2 \mathrm{ng} / \mathrm{ml}$ ) (lanes 6 and 12) for $1 \mathrm{~h}$. Cell lysates were prepared following stimulation and analyzed for $\mathrm{I}_{\kappa} \mathrm{B} \alpha$ degradation as described under "Experimental Procedures." Closed and open arrows indicate the positions of the $\mathrm{I}_{\kappa} \mathrm{B} \alpha$ inhibitor protein and its phosphorylated form, respectively. Molecular mass markers are shown in $\mathrm{kDa}$ (right). Results are representative of three separate experiments. $C$, HL60 cells (either parental or MX2), seeded overnight $\left(1 \times 10^{6} / \mathrm{ml}\right)$ in media supplemented with $0.5 \%$ FBS ( $3 \mathrm{ml}$ total), were treated with either bleomycin $(B l m)$ $(10 \mu \mathrm{M})$ for $2 \mathrm{~h}$ (lanes 2 and 4 ) or vehicle control $(C)$ (lanes 1 and 3). Cell lysates were prepared following stimulation and analyzed for $\mathrm{I} \kappa \mathrm{B}$

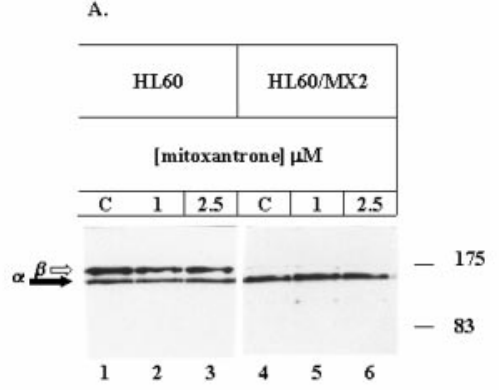

B.

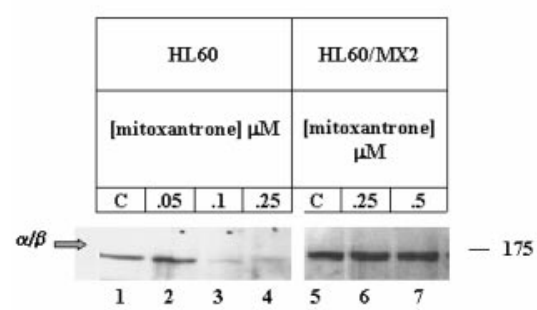

c.

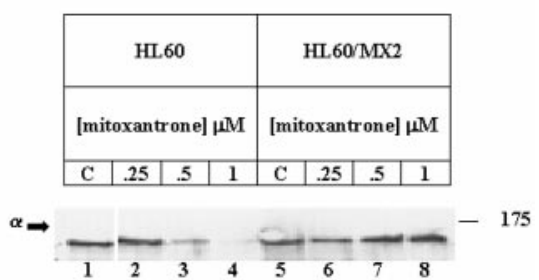

D.

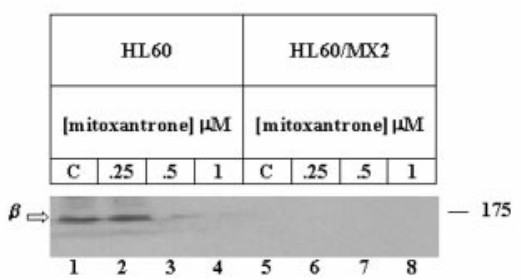

FIG. 2. Topoisomerase II $\alpha$ and $\beta$ are targeted by mitoxantrone in HL60 promyelocytic leukemia cells but not in the variant MX2 cell line, which lacks topoisomerase II $\beta$, and has a mutated $\alpha$ isoform that is resistant to mitoxantrone action. HL60 cells (either parental or MX2) seeded overnight $\left(2 \times 10^{6} / \mathrm{ml}\right)$ in media supplemented with $0.5 \%$ FBS were stimulated with either mitoxantrone (concentrations indicated) or vehicle control $(C)$ (media) as indicated for $4 \mathrm{~h}$. A, whole cell extracts were prepared and analyzed for the presence of topoisomerase II isoforms as described under "Experimental Procedures." The position of topoisomerase II $\alpha$ and $\beta$ proteins are indicated. Nuclear extracts were prepared for band depletion analysis as described under "Experimental Procedures" and analyzed for the depletion of topoisomerase II total $(B)$, topoisomerase II $\alpha(C)$ or topoisomerase II $\beta(D)$, as described under "Experimental Procedures." Closed and open arrows indicate the positions of topoisomerase II $\alpha$ and $\beta$ proteins, respectively. Molecular mass markers are shown in $\mathrm{kDa}$. Results are representative of three separate experiments.

than inhibition, is the more potent signal for $\mathrm{NF}_{\kappa} \mathrm{B}$ activation. This observation was supported by the inability of similar doses of ICRF 187 to induce apoptosis in parental HL60 cells (Fig. 4B, lanes 3-7) as determined by measurement of caspase 3 degradation/activation in extracts from treated cells. $1 \mu \mathrm{M}$

degradation as described under "Experimental Procedures." Molecular mass markers are shown in $\mathrm{kDa}($ right $)$. 


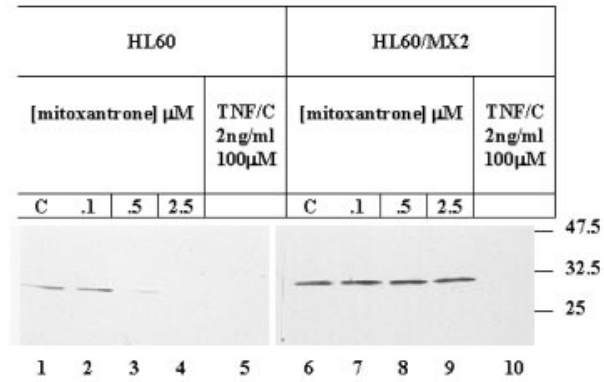

FIG. 3. Mitoxantrone stimulates caspase 3 activation in parental HL60 promyelocytic leukemia cells but not in the variant MX2 cell line. HL60 cells (either parental or MX2), seeded overnight $\left(1 \times 10^{6} / \mathrm{ml}\right)$ in media supplemented with $0.5 \%$ FBS $(3 \mathrm{ml}$ total $)$, were treated with either mitoxantrone (concentrations indicated) (lanes 2-5 and 7-9) or an equivalent volume of vehicle control (C) (media) (lanes 1 and 7) for $4 \mathrm{~h}$. Alternatively, cells were treated with TNF and cycloheximide $(T N F / C)(2 \mathrm{ng} / \mathrm{ml}$ and $100 \mu \mathrm{M}$, respectively) (lanes 5 and 10) for $4 \mathrm{~h}$. Cell lysates were prepared following stimulation and analyzed for degradation of the proform of caspase 3 as described under "Experimental Procedures." Molecular mass markers are shown in $\mathrm{kDa}$ (right). Results are representative of three experiments.

A.

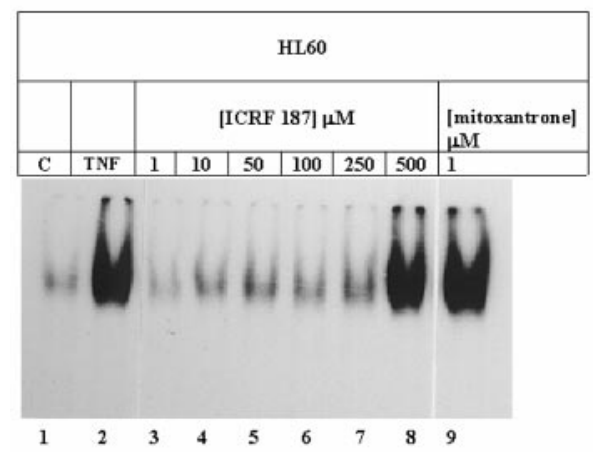

B.

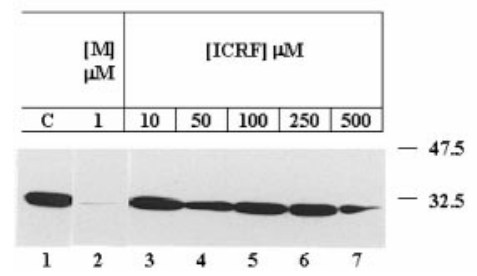

FIG. 4. The topoisomerase II inhibitor, ICRF 187, only marginally activates $\mathrm{NF} \kappa \mathrm{B}$ in parental $\mathrm{HL60}$ promyelocytic leukemia cells and does not stimulate caspase 3 activation. $A$, parental HL60 cells were seeded overnight $\left(1 \times 10^{6} / \mathrm{ml}\right)$ in media supplemented with $0.5 \%$ FBS and treated with either ICRF 187 (concentrations indicated) (lanes 3-8) or an equivalent volume of vehicle control (C) (media) (lane 1) for $4 \mathrm{~h}$. Alternatively, cells were treated with either TNF (2 $\mathrm{ng} / \mathrm{ml}$ ) (lane 2) for $1 \mathrm{~h}$ or mitoxantrone $(1 \mu \mathrm{M})$ for $4 \mathrm{~h}$, for comparison. Nuclear extracts were prepared following stimulation and analyzed for $\mathrm{NF} \kappa \mathrm{B}$ binding activity as described under "Experimental Procedures." $\mathrm{NF}_{\kappa} \mathrm{B}$-DNA complexes are shown. Results are representative of three separate experiments. $B$, parental HL60 cells were seeded overnight $\left(1 \times 10^{6} / \mathrm{ml}\right)$ in media supplemented with $0.5 \%$ FBS and treated with either ICRF 187 (concentrations indicated) (lanes 3-8) or an equivalent volume of vehicle control (medium) (lane 1) for $4 \mathrm{~h}$. Alternatively, cells were treated with mitoxantrone $(M)(1 \mu \mathrm{M})$ (lane 2$)$ only for $4 \mathrm{~h}$. Cell lysates were prepared following stimulation and analyzed for degradation of the pro-form of caspase 3 as described under "Experimental Procedures." Molecular mass markers are shown in $\mathrm{kDa}$ (right).

mitoxantrone induced degradation of the pro-form of caspase 3 as expected (Fig. 4B, lane 2). However, a concentration of 500 $\mu \mathrm{M}$ ICRF 187 was required to see any pro-caspase 3 degradation (lane 7).
Both ICRF 187 and Merbarone Protect against I $B$ Degradation in Parental HL60 Cells in Response to the Topoisomerase II Poison Mitoxantrone-We then exploited the reported ability of ICRF 187 to protect topoisomerase against mitoxantrone. As shown in Fig. 5A, pretreatment of parental HL60 cells with doses of ICRF 187 that did not activate $\mathrm{NF}_{\kappa} \mathrm{B}$ protected in part against $\mathrm{NF} \kappa \mathrm{B}$ activation (as measured by $\mathrm{I} \kappa \mathrm{B} \alpha$ degradation) in response to the topoisomerase II poison mitoxantrone. Treatment of HL60 cells with $1 \mu \mathrm{M}$ mitoxantrone induced an almost complete degradation of $\mathrm{I} \kappa \mathrm{B} \alpha$ (Fig. 5 A, lane 2). A concentration of $250 \mu \mathrm{M}$ ICRF had no effect (lane 3). However, pretreatment of HL60 cells with 10-250 $\mu \mathrm{M}$ ICRF 187 decreased the ability of $1 \mu \mathrm{M}$ mitoxantrone to induce $\mathrm{I} \kappa \mathrm{B} \alpha$ degradation (lanes 4-7), as indicated by less degradation being evident. Some phosphorylation (as indicated by the upper band, corresponding to phospho-I $\kappa \mathrm{B} \alpha(9,14))$ and degradation (less $\mathrm{I} \kappa \mathrm{B} \alpha$ being detected) was evident, but the effect of mitoxantrone was clearly impaired, particularly at concentrations of 50-250 $\mu \mathrm{M}$ ICRF 187 (Fig. 5A, compare lanes 5-7 with lane 2). Importantly, I $\kappa \mathrm{B} \alpha$ degradation following treatment of HL60 cells with the cytokine TNF, was not protected against by pretreatment with ICRF (Fig. 4B, compare lanes 3 and 4 with lane 2).

The same experiment was performed with merbarone, a topoisomerase II inhibitor that is structurally and functionally distinct from ICRF 187 and has previously been shown to attenuate etoposide-enhanced topoisomerase II-mediated DNA cleavage (57). As shown in Fig. 5C, merbarone dose-responsively protected against $\mathrm{I} \kappa \mathrm{B} \alpha$ degradation (lanes $4-8$ ) induced by $1 \mu \mathrm{M}$ mitoxantrone (lane 2) in parental HL60 cells. A dose of $100 \mu \mathrm{M}$ merbarone completely protected against mitoxantroneinduced $\mathrm{I} \kappa \mathrm{B} \alpha$ degradation, where the intensity of the band corresponding to the $\mathrm{I} \kappa \mathrm{B} \alpha$ protein was comparable with that from untreated cells (Fig. $5 C$, compare lanes 1 and 8 ). This dose did not induce $\mathrm{I} \kappa \mathrm{B} \alpha$ degradation on its own (lane 3). As with ICRF 187, I $\kappa \mathrm{B} \alpha$ degradation following treatment of HL60 cells with the cytokine TNF was not protected against by pretreatment with merbarone (Fig. $5 D$, compare lanes 3 with lane 2). This suggested that the effect was specific for a stimulus that targeted topoisomerase II, with DNA damage being a prerequisite lesion for this signal.

Taken together, our data indicate that DNA damage driven by topoisomerase II poisoning is the mechanism whereby the anthracenedione mitoxantrone activates $\mathrm{NF}_{\kappa} \mathrm{B}$.

\section{DISCUSSION}

In order to specifically address the role of topoisomerase II enzymes in mediating $\mathrm{NF}_{\kappa} \mathrm{B}$ activation in response to mitoxantrone, we chose a resistant variant of the promyelocytic cell line HL60, namely HL60/MX2 (43, 44). These cells lack topoisomerase II $\beta$ isoform expression and have a disruption in the carboxyl terminus of the $\alpha$ isoform. Furthermore, altered cellular distribution of the $\alpha$ isoform, as detected by immunofluorescence microscopy has been reported for these cells (53). These changes are the likely explanation for why the DNA cleavage activity of topoisomerase II present in the MX2 cell line is less sensitive to inhibition by mitoxantrone when compared with the parental cell line. Our results show an absence of $\mathrm{NF} \kappa \mathrm{B}$ activation and $\mathrm{I} \kappa \mathrm{B}$ degradation in this cell line following treatment with mitoxantrone. This is the first indication that topoisomerase II is absolutely required by mitoxantrone to mediate this activation.

Using a band depletion assay, we showed that both topoisomerase II $\alpha$ and $\beta$ were targeted by mitoxantrone in parental HL60 cells following the formation of transient DNA-topoisomerase II complexes. Furthermore, the absence of a depleted band corresponding to the $\alpha$ isoform in the variant cells, HL60/ MX2, indicated that this altered form was unable to compen- 
A.

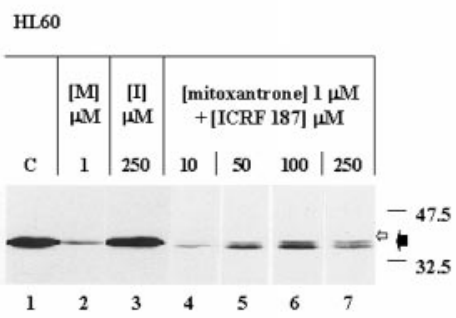

B.

\section{HL60}

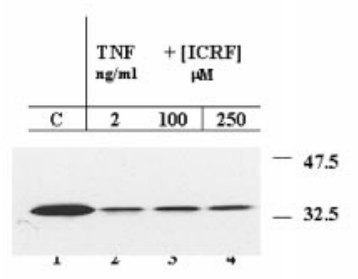

c.

HL60

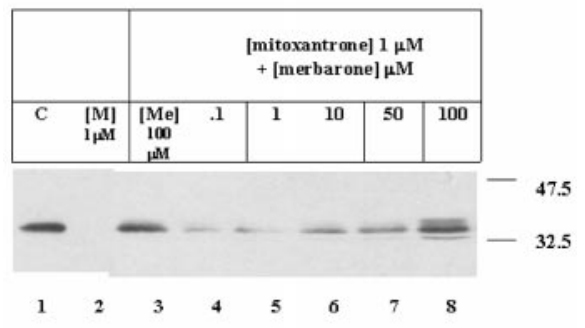

D.

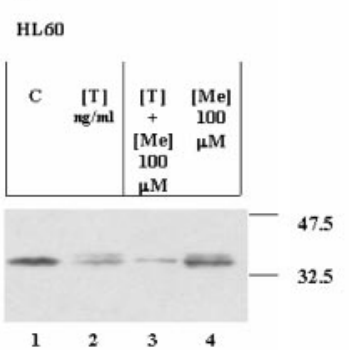

FIG. 5. The topoisomerase II inhibitors ICRF 187 and merbarone protect against $I \kappa B$ degradation in response to mitoxantrone but not TNF in parental HL60 promyelocytic leukemia cells. $A$, parental HL60 cells were seeded overnight $\left(1 \times 10^{6} / \mathrm{ml}\right)$ in media supplemented with $0.5 \% \mathrm{FBS}$ and preincubated with ICRF 187 (concentrations indicated) (lanes 4-7) for $1 \mathrm{~h}$ prior to treatment with mitoxantrone $(1 \mu \mathrm{M})$. Alternatively, cells were treated with mitoxantrone $(M)(1 \mu \mathrm{M})$ (lane 2) or ICRF 187 only $(I)$ (lane 3) for $4 \mathrm{~h} . B$, parental HL60 cells were preincubated with ICRF 187 (concentrations indicated) (lanes 3 and 4 ) for $1 \mathrm{~h}$ prior to treatment with TNF $(2 \mathrm{ng} / \mathrm{ml})$ for $1 \mathrm{~h}$. Alternatively, cells were treated with TNF (2 ng/ml) (lane 2) alone for $1 \mathrm{~h}$. C, parental HL60 cells were preincubated with merbarone (concentrations indicated) (lanes 4-8) for $1 \mathrm{~h}$ prior to treatment with mitoxantrone $(1 \mu \mathrm{M})$. Alternatively, cells were treated with mitoxantrone $(1 \mu \mathrm{M})$ (lane 2$)$ or merbarone $(M e)$ only (lane 3$)$ for $4 \mathrm{~h}$. $D$, parental HL60 cells were preincubated with merbarone (concentrations indicated) (lanes 3 and 4 ) for $1 \mathrm{~h}$ prior to treatment with TNF $(2 \mathrm{ng} / \mathrm{ml})$ for $1 \mathrm{~h}$. Alternatively, cells were treated with TNF (2 ng/ml) (lane 2) alone for $1 \mathrm{~h}$. In all cases, cell lysates were prepared following stimulation and analyzed for I $\kappa \mathrm{B} \alpha$ degradation as described under "Experimental Procedures" and above. Molecular mass markers are shown in $\mathrm{kDa}($ right). Results are representative of at least three separate experiments. sate for the absence of the $\beta$ isoform in mediating mitoxantrone-induced DNA damage. We therefore concluded that intact topoisomerase II was required for the effect of mitoxantrone on $\mathrm{NF} \kappa \mathrm{B}$, although it was not possible to attribute the effect to either the $\alpha$ or $\beta$ isoform because the HL60/MX2 cells lacked the $\beta$ isoform and had a mutation in the $\alpha$ isoform. This would require the use of cell lines that express only $\alpha$ or $\beta$, which are currently unavailable. The preferential targeting of topoisomerase II $\beta$ by anthracyclines has been examined in other studies $(39,44)$, with evidence being presented for topoisomerase II $\beta$ poisoning being more important for cell killing. In another study, however, mitoxantrone has been shown to be preferentially toxic to yeast expressing the $\alpha$ form of the human enzyme (57). It is therefore possible that mitoxantrone can target topoisomerase II $\alpha$, but only when overexpressed, with topoisomerase II $\beta$ being the preferred endogenous target, particularly as it is this isoform that is up-regulated during transformation (31).

A number of factors are involved in the development of cellular resistance to topoisomerase II poisons. HL60/MX2 cells were recently confirmed not to exhibit changes in drug uptake or retention compared with the parental cell line, as determined by fluorescence-activated cell sorter analysis (52). In addition, these cells are normally sensitive to other anti-tumor agents such as the vinca alkaloids, resistance to which in combination with some anthracyclines characterizes the multidrug resistance phenotype (45). In a related study, the ability to repair drug-induced DNA strand breaks was shown to be comparable in both a parental and resistant cell line (58), suggesting that changes in the DNA repair capacity of the HL60/MX2 cell line might not be a factor underlying the absence of $\mathrm{NF} \kappa \mathrm{B}$ activation in response to mitoxantrone. This information, combined with our own data, was essential in concluding that the results we observed were due to changes in topoisomerase II activity and not to differential drug uptake or metabolism.

We attempted to complement the HL60/MX2 cell line with topoisomerase II $\beta$ but had difficulty expressing the gene for topoisomerase II $\beta$ in the MX2 cell line. In fact, to date no report exists in which human topoisomerase II $\beta$ has been expressed ectopically in mammalian cells, suggesting that this is a general problem. We therefore used other means to further examine the role of topoisomerase II in mitoxantrone-mediated $\mathrm{NF}_{\kappa} \mathrm{B}$ activation. This involved the use of two topoisomerase II inhibitors, ICRF 187 and merbarone. Their mechanism is distinct from the poisons and involves their interaction with the protein in its closed clamp conformation, blocking the enzymic activity but not resulting in the generation of DNA double strand breaks. This is an important distinction between topoisomerase II inhibitors and poisons in their mechanism of action. Mechanistic studies have shown that the catalytic inhibitors abrogate DNA damage and cytotoxicity caused by the topoisomerase II-targeted poisons in sensitive cells $(54,59)$. We found that ICRF 187 inhibited the ability of mitoxantrone to activate $\mathrm{NF}-\kappa \mathrm{B}$. Although only a partial protection was shown, it was dose-dependent and correlated well with data from previous reports in which ICRF 187 reduced the presence of DNA strand breaks in response to topoisomerase II poisons $(56,59)$ but not to control levels. We therefore employed a more potent inhibitor of enzyme-mediated DNA scission, merbarone (55). This thiobarbituric acid derivative is structurally and functionally distinct from the ICRF class of compounds and has been shown to block the actions of topoisomerase II-targeted DNA cleavage-enhancing drugs both in vitro and in cultured cells. Pretreatment of parental HL60 cells with merbarone completely blocked mitoxantrone-stimulated $\mathrm{I} \kappa \mathrm{B}$ degradation. Im- 
portantly, our study also showed that neither ICRF 187 nor merbarone had an effect on TNF-mediated activation of $\mathrm{NF}_{\kappa} \mathrm{B}$. This was important because ICRF 187 can chelate iron (54), and previously, we had found that other agents with this property, such as desferal, can inhibit the activation of $\mathrm{NF}_{\kappa} \mathrm{B}$ by TNF (3). Finally, the activation of $\mathrm{NF}_{\kappa} \mathrm{B}$ by a DNA-damaging agent (bleomycin) that does not target topoisomerase II was not attenuated by ICRF 187 (data not shown), supporting the specificity of this response.

Our data therefore support the proposal that DNA damage is an important signaling lesion for $\mathrm{NF}_{\kappa} \mathrm{B}$ activation, following either topoisomerase II poisoning or direct effects on DNA, such as those induced by the radiomimetic agent bleomycin. It has been proposed that DNA damage by other agents may transduce signals from the nucleus to the cytoplasm, resulting in $\mathrm{NF}_{\kappa} \mathrm{B}$ activation (6). How this occurs is not known. A wide variety of proteins participate in $\mathrm{NF}_{\kappa} \mathrm{B}$ activation in response to different stimuli (8-10). Whether DNA damage activates any of these known proteins on the $\mathrm{NF}_{\kappa} \mathrm{B}$ pathway is not clear. In our study, both parental and resistant HL60 cell lines were equally sensitive to $\mathrm{NF}_{\kappa} \mathrm{B}$ activation in response to TNF. This indicates that components of the TNF pathway are intact in both cell lines. Changes or mutations in the $\mathrm{NF}_{\kappa} \mathrm{B}$ signaling proteins, such as the $\mathrm{I}_{\kappa} \mathrm{B}$ kinases, therefore, cannot account for differences in the response to topoisomerase-II targeted drugs. It remains to be determined where the mitoxantrone-mediated signal might "connect" with signaling proteins on the $\mathrm{NF} \kappa \mathrm{B}$ activation pathway.

We also monitored caspase 3 activation as a marker of apoptosis (51), as well as morphological changes in the parental and resistant cell line. We confirmed that mitoxantrone does not induce apoptosis in the resistant cell line, further emphasizing the importance of topoisomerase II in this process. Similar to $\mathrm{NF} \kappa \mathrm{B}$, the apoptotic machinery was intact in the cells, however, because TNF/cycloheximide could induce apoptosis. How topoisomerase II-mediated DNA damage might lead to caspase 3 activation is at present unknown.

The importance of our observation is underscored by the emerging role of $\mathrm{NF} \kappa \mathrm{B}$ in cancer and tumor resistance $(10,60)$. Both pro- and anti-apoptotic roles have been proposed for $\mathrm{NF}_{\kappa} \mathrm{B}$. Activated $\mathrm{NF}_{\kappa} \mathrm{B}$ has been implicated in the development of resistance to TNF and anti-cancer drugs $(60,61)$ via the induction of anti-apoptotic genes (62). Although fewer proapoptotic genes have been identified that are regulated by $\mathrm{NF} \kappa \mathrm{B}$, Fas ligand (Fas L), a physiological inducer of this process, has recently been shown to contain $\mathrm{NF}_{\kappa} \mathrm{B}$ consensus sequences in its promoter region (63), and interestingly, it is up-regulated in response to DNA damage (59). The expression of Fas ligand is increased following treatment of cells with topoisomerase II poisons and this is regulated in part by the presence of $\mathrm{NF}_{\kappa} \mathrm{B}$ binding sites in its promoter (59). These data suggest that Fas ligand expression in response to such drugs is dependent on a functional $\mathrm{NF} \kappa \mathrm{B}$ activation pathway, supporting a pro-apoptotic role for this transcription factor and presenting Fas ligand as a possible candidate for inducing apoptosis in response to such drugs. Our study provides a mechanism whereby topoisomerase II poisons might activate $\mathrm{NF}_{\kappa} \mathrm{B}$ and thereby increase Fas ligand expression.

In conclusion, we have shown that topoisomerase II mediates the activation of the transcription factor, $\mathrm{NF}_{\kappa} \mathrm{B}$, in response to mitoxantrone. This process may be important for the mechanism of action of anti-cancer drugs and their clinical efficacy.

Acknowledgments-HL60 parental and variant HL60/MX2 cell lines were generously provided by Dr. G. Harker (Department of Veterans Affairs Medical Center, Salt Lake City, UT) by way of Prof. Ian Hickson ICRF (Oxford, United Kingdom). We also thank Prof. Ian Hickson and Dr. Andrew Bowie for many helpful discussions.
REFERENCES

1. Beiquig, L., Chen, M., and Whisler, R. L. (1996) J. Immunol. 157, 160-169

2. Boland, M. P., Foster, S. J., and O'Neill, L. A. (1997) J. Biol. Chem. 272, 12952-12960

3. Bowie, A. G., Moynagh, P. N., and O'Neill, L. A. (1997) J. Biol. Chem. 272, 25941-25950

4. Brach, M. A., Hass, R., Sherman, M. L., Gunji, H., Weichselbaum, R., and Kufe, D. (1991) J. Clin. Invest. 88, 691-695

5. Furuke, K, Shiraishi, M., Mostowski, H. S., and Bloom, E. T. (1999) J. Immunol. 162, 1988-1993

6. Legrand-Poels, S., Bours, V., Piret, B., Pflaum, M., Epe, B., Rentier, B., and Piette, J. (1995) J. Biol. Chem. 270, 6925-6934

7. Wilson, R. E., Taylor, S. L., Atherton, G. T., Johnston, D., Waters, C. M., and Norton, J. D. (1993) Oncogene 8, 3229-3237

8. Baeuerle, P. A., and Henkel, T. (1994) Annu. Rev. Immunol. 12, 141-179

9. Baeuerle, P. A., and Baltimore, D. (1996) Cell 87, 13-20

10. Gilmore, T. D., Koedood, M, Piffat, K. A., and White, D. W. (1996) Oncogene 13, 1367-1378

11. Boland, M. P., and O'Neill, L. A. (1998) J. Biol. Chem. 273, 15494-15500

12. Kang, S.-M., Tran, A.-C., Grilli, M., and Lenardo, M. J. (1992) Science 256, 1452-1455

13. Whiteside, S. T., and Israel, A. (1997) Semin. Cancer Biol. 8, 75-82

14. Traenckner, E. B.-M., Pahl, H. L., Henkel, T., Schmidt, K. N., Wilk, S., and Baeuerle. P. A. (1995) EMBO J. 14, 2876-2883

15. Henkel, T., Machleidt, T., Alkalay, I., Kronke, M., Ben-Neriah, Y., and Baeuerle, P. A. (1993) Nature 365, 182-185

16. Yaron, A., Hatzubai, A., Davis, M., Lavon, I., Amit, S., Manning, A. M. Andersen, J. S., Mann, M., Mercurio, F., and Ben-Neriah, Y. (1998) Nature 396, 590-594

17. Stancovski, I., and Baltimore, D. (1997) Cell 91, 299-302

18. Cohen, L., Henkel, W. J., and Baeuerle, P. A. (1998) Nature 395, 292-296

19. Rothwarf, D. M., Zandi, E., Natoli, G., and Karin, M. (1998) Nature 395 , 297-301

20. Yamaoka, S., Courtois, Bessia, C., Whiteside, S. T., Weil, R., Agou, F., Kirk, H. E., Kay, R. J., and Israel, A. (1998) Cell 93, 1231-1240

21. Baeuerle, P. A. (1998) Curr. Biol. 8, R19-R22

22. Darnay, B. G., and Aggarwal, B. B. (1997) J. Leukocyte Biol. 61, 559-566

23. Woronicz, J. D., Gao, X., Cao, Z., Rothe, M., and Goeddel, D. V. (1997) Science 278, 866-869

24. Shinkura, R, Kitada, K, Matsuda, F, Tashiro, K, Suzuki, M, Kogishi, K, Serikawa, T., and Honjo, T. (1999) Nat. Genet. 22, 74-77

25. Flohe, L., Brigelius Flohe, R., Saliou, C., Traber, M. G., and Packer, L. (1997) Free Radic. Biol. Med. 22, 1115-1126

26. Bose. R., Verheij, M., Haimovitz-Friedman, A., Scotto, K., Fuks, Z., and Kolesnick, R. (1995) Cell 82, 405-414

27. Gerwirtz, D. A. (1999) Biochem. Pharmacol. 57, 727-741

28. Fisher, G. R., and Patterson, L. H. (1992) Cancer Chemother. Pharmacol. 30, 451-458

29. Vile, G. F., and Winterbourne, C. C. (1989) Cancer Chemother. Pharmacol. 24, $105-108$

30. Burden, D. A., and Osheroff, N. (1998) Biochim. Biophys. Acta 1400, 139-155

31. Wang, J. C. (1996) Annu. Rev. Biochem. 65, 635-692

32. Isaacs, R. J., Davies, S. L., Sandri, M. I., Redwood, C., Wells, N. J., and Hickson, I. D. (1998) Biochim. Biophys. Acta 1400, 121-139

33. Drake, F. H., Hofmann, G. A., Bartus, H. F., Mattern, M. R., Crooke, S. T., and Mirabelli, C. K. (1989) Biochemistry 28, 8154-8160

34. Cowell, I. G., Willmore, E., Chalton, D., Marsh, K. L., Jazrawi, E., Fisher, L. M., and Austin, C. A. (1998) Exp. Cell. Res. 243, 232-240

35. Redwood, C., Davies, S. L., Wells, N. J., Fry, A. M., and Hickson, I. D. (1998) J. Biol. Chem. 273, 3635-3642

36. Wells, N. J., and Hickson, I. D. (1995) Eur. J. Biochem. 231, 491-497

37. Capranico, G., and Binaschi, M. (1998) Biochim. Biophys. Acta 1400, 185-195

38. Davies, S. M., Robson, C. N., Davies, S. L., and Hickson, I. D. (1988) J. Biol. Chem. 263, 17724-17729

39. Brown, G. A., McPherson, J. P., Gu, L., Hedley, D. W., Toso, R., Deuchars, K. L., 40 Freedman, M. H., and Goldenberg, G. J. (1995) Cancer Res. 55, $78-82$

40. Fry, A. M. Chresta, C. M., Davies, S. M., Walker, M. C., Harris, A. L., Hartley, J. A., Masters, J. R. W., and Hickson, I. D. (1991) Cancer Res. 51, 6592-6595

41. Gieseler, F., Glasmacher, A., Kampfe, D., Wandt, H., Nuessler, V., Valsamas, S., Kunze, J., and Wilms, K. (1996) Leukemia 10, Suppl. 3, S46-S49

42. McPherson, J. P., Deffie, A. M., Jones, N. R., Brown, G. A., Deuchars, K. L. and Goldenberg, G. J. (1997) Anticancer Res. 17, 4243-4252

43. Son, Y. S., Suh, J. M., Ahn, S. H., Kim, J. C., Yi, J. Y., Hur, K. C., Hong, W.-S., Muller, M. T., and Chung, I. K. (1998) Cancer Chemother. Pharmacol. 41, 353-360

44. Errington, F., Willmore, E., Tilby, M. J., Li, L., Li, G., Li W., Baguley, B. C., and Austin, C. A. (1999) Mol. Pharmacol. 56, 1309-1316

45. Harker, W. G., Slade, D. L., Dalton, W. S., Meltzer, P. S., and Trent, J. M (1989) Cancer Res. 49, 4542-4549

46. Harker, W. G., Slade, D. L., Drake, F. H., and Parr, R. L. (1991) Biochemistry 30, 9953-9961

47. Harker, W. G., Slade, D. L., Parr, R. L., and Hoguin, M. H. (1995) Cancer Res. 55, 4962-4971

48. Hann, C., Evans, D. L., Fertala, J., Benedetti, P., Bjornsti, M., and Hall, D. J. (1998) J. Biol. Chem 273, 8425-8533

49. Sikic, B. I (1986) Cancer Surv. 5, 81-91

50. Mo, Y.-Y., and Beck, W. (1999) Exp. Cell Res. 252, 50-62

51. Thornberry, N. A., and Lazebnik, Y. (1998) Science 281, 1312-1316

52. Consoli, U., Van, N. T., Neamati, N., Mahadevia, R., Beran, M., Zhao, S., and Andreeff, M. (1997) Leukemia 11, 2066-2074

53. Weiss, G., Loyevsky, M., and Gordeuk, V. R. (1999) Gen. Pharmacol. 32, 
$155-158$

54. Sehested, M., Jensen, P. B., Sorensen, B. S., Holm, B., Friche, E., and Demant,

E. J. F. (1993) Biochem. Pharmacol. 46, 389-393

55. Jensen, P. B., and Sehested, M. (1997) Biochem. Pharmacol. 54, 755-759

56. Fortune, J. M., and Osheroff, N. (1998) J. Biol. Chem. 273, 17643-17650

57. Meczes, E. L., Marsh, K. L., Fisher, L. M., Rogers, M. P., and Austin, C. A. (1997) Cancer Chemother. Pharmacol. 39, 367-375

58. Robson, C. N., Hoban, P. R., Harris, A. L., and Hickson, I. D. (1987) Cancer Res.
47, 1560-1565

59. Mo, Y.-Y., and Beck, W. T. (1999) Mol. Pharmacol. 55, 216-222

60. Baichwal, V. R., and Baeuerle, P. A. (1997) Curr. Biol. 7, R94-R96

61. Wang, C.-Y., Mayo, M. W., and Baldwin, A. S. (1996) Science 274, 784-787

62. LaCasse, E. C., Baird, S., Korneluk, R. G., and MacKenzie, A. E. (1998) Oncogene 17, 3247-3259

63. Kasibhatla, S., Genestier, L., and Green, D. R. (1999) J. Biol. Chem. 274, 987-992

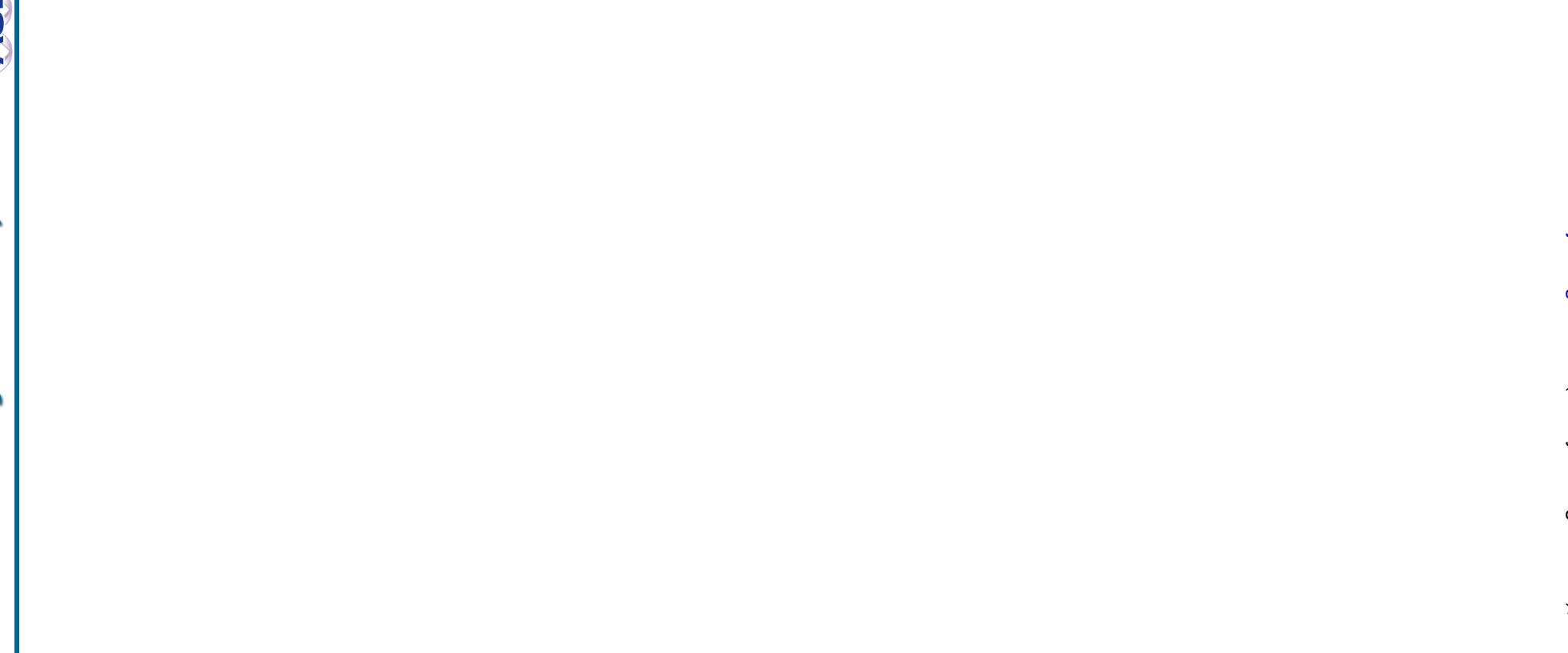

